\title{
Nurses' working tasks and MSDs back symptoms: results from a national survey
}

\author{
Serranheira, Florentino ${ }^{\mathrm{a},{ }^{*}}$, Cotrim, Teresa $^{\mathrm{b}}$, Rodrigues, Victor ${ }^{\mathrm{c}}$, Nunes, Carla ${ }^{\mathrm{d}}$ and Sousa-Uva, António ${ }^{\mathrm{e}}$ \\ a, d, ${ }^{2}$ National Public Health School, New University of Lisbon, Avenida Padre Cruz, 1600-560 Lisbon, Portugal \\ and CMDT - Malaria and Tropical Diseases Research Center - Public Health, Lisbon, Portugal \\ ${ }^{\mathrm{b}}$ Human Kinetic Faculty, Technical University of Lisbon, Estrada da Costa, 1499-002 Cruz Quebrada - Dafundo, \\ Lisbon, Portugal \\ ${ }^{\mathrm{c}}$ Nursing College of Vila Real/CIDESD/University of Trás-os-Montes and Alto Douro, Lugar do Tojal, Lordelo, \\ 5000-232 Vila Real, Portugal
}

\begin{abstract}
Healthcare workers, namely registered nurses (RN), are frequently exposed to work-related musculoskeletal disorders (WRMSDs) risk factors. Identifying the symptoms of these disorders is one of the first epidemiological steps to managing them. This study aims to identify WRMSDs prevalence symptoms in Portuguese RN. During 8 months (2010-2011) the National Public Health School and the Portuguese Registered Nurses Board made a call to all RN to answer an online WRMSDs questionnaire. Respondents $(\mathrm{n}=2140)$ are mostly females $(77.4 \%)$ and work mainly in hospitals $(\mathrm{n}=1396)$ and in primary healthcare centers $(\mathrm{n}=421)$. Results show high symptoms prevalence (last 12 months) in the lower back $(60.6 \%)$, the upper back $(44.5 \%)$, and the neck (48.6\%). Nurses' activity, especially patient hygiene in bed, is a strong contributor $(p<0.05)$ to pain in the upper back $(\mathrm{OR}=1.39$ [1.09-1.80]) and lower back $(\mathrm{OR}=1.4$ [1.08-1.84]). Patient holdup without mechanical support has the highest relationship $(p<0.05)$ between work tasks and symptoms in the last 12 months in the upper back $(\mathrm{OR}=1.50$ [1.19-1.90]). Prevalence rates of WRMSDs symptoms in Portuguese nurses are no different from other studies with Swedish, Italian and Greek nurses. Maybe changes in healthcare systems didn't change the way care is delivered and we must rethink how to prevent nurses WRMSDs.
\end{abstract}

Keywords: nurses, WRMSDs symptoms, epidemiology, ergonomics

\section{Introduction}

Musculoskeletal disorders (MSDs) are a significant worker health related problem with a colossal social and economic impact and their symptoms are very common in working populations [1]. Workrelated musculoskeletal disorders (WRMSDs) frequently affect healthcare professionals, namely nurses [2-4].

WRMSDs encompass a variety of conditions and nevertheless their etiology is still not consensual and the symptom complex is very similar [5]. WRMSDs have been frequently linked with work and workplace risk factors and they were described as one of the main occupational problems among healthcare workers [6].
Nursing work is one of the most dangerous occupations and has a particular risk of back injury during patient lifting or patient transfer [7].

Nevertheless the health care system changes, the loss of nurses and the cost resulting from WRMSDs warrant preventive intervention [8].

Identifying workers (and their jobs) with symptoms can aid prevention. Recognizing this, early symptoms detection may be used to identify the prevalence of WRMSDs and to allow successful interventions [9].

Worker self-completed musculoskeletal questionnaires were used in healthcare epidemiological surveys as an approach to seeking information about WRMSDs prevalence symptoms [2, 10-12].

\footnotetext{
${ }^{*}$ Corresponding author. E-mail: serranheira@ensp.unl.pt
} 
They are commonly used in Occupational Health and Safety surveillance programs since they are considered as simple and valid tools for gathering information about workers, work tasks, and symptoms [13], and for the assessment of risk factors [14].

This study aims at identifying WRMSDs symptoms in Portuguese registered nurses.

\section{Population and methods}

This study was a national cross-sectional survey and includes all the registered nurses (RN) on the Portuguese Nurses Board ( $n=62.566)$. All Portuguese nurses (males and females) were invited to participate in this national musculoskeletal disorders survey from a call on the Board web site.

Responders had to accept the invitation writing their own e-mail at the "surveymonkey platform questionnaire" webpage. After that, they received a link to answer online.

The call for this study was pending for 8 months until February 2011.

The used questionnaire is an adaptation of the Nordic musculoskeletal questionnaire (NMQ) that was frequently used in Portugal [3, 13, 15-17]. WRMSDs symptoms (ache, discomfort and pain) in a detailed body map (last 12 months, and last 7 days in dichotomous yes/no response) and the frequency and severity (scale with four degrees) at nine anatomical body regions are the main dependent variables. There was also a socio-demographic and health status characterization. Symptoms were analyzed with the nurses tasks (strenuous back postures, high demands with arms, and manual material/patient handling), by odds-ratio (OR), and 95\% confidence intervals (CI), calculated to estimate the relative risk.

\section{Results}

Respondents $(\mathrm{n}=2140)$ were all Portuguese registered nurses. The mean age and BMI were 37.8 $( \pm 9.5)$ years and $24.62( \pm 7.9)$, respectively. Female nurses were $77.4 \%$ of the sample. Respondents worked mainly in hospitals $(\mathrm{n}=1396)$, and in primary healthcare centers $(n=421)$. The main symptoms prevalence in different anatomical body regions were (Table 1):
Table 1

Symptoms prevalence

\begin{tabular}{|l|c|c|}
\hline \multirow{2}{*}{$\begin{array}{c}\text { Anatomical } \\
\text { region }\end{array}$} & \multicolumn{2}{|c|}{ Symptoms prevalence (\%) } \\
\cline { 2 - 3 } & last 12 months & last 7 days \\
\hline lower back & 60.6 & 29.5 \\
\hline neck & 48.6 & 25.8 \\
\hline upper back & 44.5 & 21.1 \\
\hline
\end{tabular}

Diagnosis criteria by means of symptoms that were present in the last 12 months and in the last 7 days show at lower back $(n=632)$ and neck $(n=553)$ high WRMSDs prevalence.

Daily demands in the nurses' work were strong contributors to pain and the highest was manual material/patient handling $(80.9 \%)$. Work demands were analysed from infrequent and frequent demands $(<=5$ and $>=6$ per/day) as a predictor for back pain (Table 2):

Table 2

Relationships between work tasks and symptoms in last 12 months

\begin{tabular}{|l|c|c|c|}
\hline Work task & Neck pain & $\begin{array}{c}\text { Upper back } \\
\text { pain }\end{array}$ & $\begin{array}{c}\text { Lower back } \\
\text { pain }\end{array}$ \\
\hline $\begin{array}{l}\text { Patient } \\
\text { Hygiene-bed }\end{array}$ & $1.09[0.85-1.40]$ & $1.39[1.09-1.80]^{*}$ & $1.40[1.08-1.84]^{*}$ \\
\hline $\begin{array}{l}\text { Positioning } \\
\text { in bed }\end{array}$ & $1.03[0.85-1.26]$ & $1.36[1.11-1.66]^{*}$ & $1.16[0.94-1.43]$ \\
\hline Transfers & $1.13[0.90-1.42]$ & $1.42[1.13-1.79]^{*}$ & $1.24[0.97-1.58]$ \\
\hline $\begin{array}{l}\text { Patient holdup } \\
\text { (no mechani- } \\
\text { cal support) }\end{array}$ & $1.03[0.81-1.30]$ & $1.50[1.19-1.90]^{*}$ & $1.20[0.94-1.54]$ \\
\hline $\begin{array}{l}\text { Drug admin- } \\
\text { istration }\end{array}$ & $0.96[0.80-1.16]$ & $1.18[0.98-1.43]$ & $1.37[1.13-1.66]^{*}$ \\
\hline $\begin{array}{l}\text { Domiciliary } \\
\text { support }\end{array}$ & $1,45[0,99-2,11]$ & $1,35[0,93-1,96]$ & $1,78[1,18-2,66]^{*}$ \\
\hline $\begin{array}{l}\text { Standing / } \\
\text { walking }\end{array}$ & $1,36[1,11-$ & $1,83[1,49-2,26]^{*}$ & $2,31[1,87-2,86]^{*}$ \\
\hline \multicolumn{2}{|l|}{ * Significant $(p<0.05)}$. &
\end{tabular}

\section{Discussion and conclusions}

Our sample was obtained from a national survey (3.42\% of all Portuguese registered nurses). Results denote a high WRMSDs symptoms prevalence in Portuguese nurses. Although, these results were no different from some other studies [3, 4, 11, 18-21] and they all indicate that nurses are at risk to develop WRMSDs (Table 3): 
Table 3

Studies WRMSDs symptoms prevalence

\begin{tabular}{|l|c|c|c|c|}
\hline \multirow{2}{*}{ Study } & \multicolumn{4}{|c|}{ Symptoms prevalence (\%) } \\
\cline { 2 - 5 } & $\begin{array}{l}\text { Low } \\
\text { back }\end{array}$ & $\begin{array}{l}\text { Upper } \\
\text { back }\end{array}$ & Neck & Shoulder \\
\hline $\begin{array}{l}\text { Lagerstrom et al. } \\
\text { (1995) }\end{array}$ & 56 & - & 48 & 53 \\
\hline Engels et al. (1996) & 34 & 22 & 23 & 20 \\
\hline Ando et al. (2000) & 54.7 & - & 31.3 & 42.8 \\
\hline Alexopoulos (2003) & 75 & - & 47 & 37 \\
\hline $\begin{array}{l}\text { Trinkoff et al. } \\
\text { (2002) }\end{array}$ & 47 & - & 45,8 & 35,1 \\
\hline Smith et al. (2004) & 56 & 37 & 45 & 40 \\
\hline $\begin{array}{l}\text { Trinkoff et al. } \\
\text { (2004) }\end{array}$ & 32 & 24 & - & 22 \\
\hline $\begin{array}{l}\text { Fonseca and Ser- } \\
\text { ranheira (2006) }\end{array}$ & 65 & 37 & 55 & 34 \\
\hline This study (2011) & 60.6 & 44.5 & 48.6 & 36.7 \\
\hline
\end{tabular}

Results show (again) that some frequent nurses' daily activities (work tasks) were related with back pain. Questions about work tasks/activities should be used in surveys as pain predictors.

Symptoms are common in the lower and upper back which can be strong evidence to promote the need of occupational changes such as a hospital nolift policy. That means, whenever possible, $\mathrm{RN}$ and nurses aids should minimize the risk of back injury during such lifting, transferring and positioning operations with the use of mechanical aids as sliding boards, lifting belts or lifting hoists, for instances.

\section{References}

[1] Kuorinka, I., et al., Standardised Nordic questionnaires for the analysis of musculoskeletal symptoms. Applied Ergonomics, 1987. 18(3): p. 233-237.

[2] Burdorf, A., E.C. Alexopoulos, and A. Kalokerinou, Risk factors for musculoskeletal disorders among nursing personnel in Greek hospitals. International Archives of Occupational and Environmental Health, 2003. 76(4): p. 289-294.

[3] Fonseca, R. and F. Serranheira, Sintomatologia músculo-esquelética auto-referida por enfermeiros em meio hospitalar. Revista Portuguesa de Saúde Pública 2006. Volume Temático: p. 37-44.

[4] Tinubu, B.M., et al., Work-related musculoskeletal disorders among nurses in Ibadan, South-west Nigeria: a cross-sectional survey. BMC Musculoskelet Disord, 2010. 11: p. 12 .

[5] Baron, S., T. Hales, and J. Hurrell, Evaluation of symptom surveys for occupational musculoskeletal disorders. American Journal of Industrial Medicine, 1996. 29(6): p. 609-617.

[6] Lorusso, A., S. Bruno, and N. L'Abbate, A review of low back pain and musculoskeletal disorders among Italian nursing personnel. Industrial health, 2007. 45(5): p. 637-644

[7] Engkvist, I.L., et al., The accident process preceding overexertion back injuries in nursing personnel.
PROSA study group. Scand J Work Environ Health., 1998. 24(5): p. 367-75

[8] Stover, B., et al., Accuracy of a disability instrument to identify workers likely to develop upper extremity musculoskeletal disorders. J Occup Rehabil., 2007. 17(2): p. 227-45. Epub 2007 May 9

[9] Balogh, I., et al., Questionnaire-based mechanical exposure indices for large population studies reliability, internal consistency and predictive validity. Scandinavian Journal of Work Environment \& Health, 2001. 27(1): p. 41-48.

[10] Lusted, M.J., et al., Self reported symptoms in the neck and upper limbs in nurses. Applied Ergonomics, 1996. 27(6): p. 381-387.

[11] Trinkoff, A.M., et al., Musculoskeletal problems of the neck, shoulder, and back and functional consequences in nurses. Am J Ind Med, 2002. 41(3): p. 170-8.

[12] Trinkoff, A.M., et al., Perceived physical demands and reported musculoskeletal problems in registered nurses. American Journal of Preventive Medicine, 2003. 24(3): p. 270-275.

[13] Serranheira, F., A. Uva, and F. Lopes, Lesões músculoesqueléticas e trabalho: alguns métodos de avaliação do risco. Cadernos Avulso. 2008, Lisboa: Sociedade Portuguesa de Medicina do Trabalho.

[14] Andersen, J.H., et al., [Computer use and carpal tunnel syndrome: a 1-year follow-up study]. Ugeskr Laeger, 2004. 166(33): p. 2804-7.

[15] Serranheira, F., et al., Auto-referência de sintomas de lesões músculo-esqueléticas ligadas ao trabalho (LMELT) numa grande empresa em Portugal. Revista Portuguesa de Saúde Pública, 2003. 2: p. 37-48.

[16] Serranheira, F., A. Uva, and J. Espirito-Santo, Risco de LMEMSLT em actividades de abate e desmancha de carnes. Saúde \& Trabalho, 2007. 6: p. 43-61.

[17] Serranheira, F., A. Uva, and J. Espirito-Santo, Estratégia de avaliação do risco de lesões músculoesqueléticas dos membros superiores ligadas ao trabalho aplicada na indústria de abate e desmancha de carne em Portugal. Revista Brasileira de Saúde Ocupacional., 2009. 34(119): p. 58-66.

[18] Andersen, J.H., et al., [Activity-based registration of computer use in epidemiological studies. Danish Society of Occupational and Environmental Medicine]. Ugeskr Laeger, 2005. 167(12-13): p. 1377.

[19] Andersen, J.H., et al., Computer mouse use predicts acute pain but not prolonged or chronic pain in the neck and shoulder. Occup Environ Med, 2008. 65(2): p. 12631.

[20] Lipscomb, J., et al., Health care system changes and reported musculoskeletal disorders among registered nurses. Am J Public Health, 2004. 94(8): p. 1431-5.

[21] Gurgueira, G.P., N.M.C. Alexandre, and H.R.C. Filho, Prevalência de sintomas músculo-esqueléticos em trabalhadoras de enfermagem. Revista LatinoAmericana de Enfermagem, 2003. 11: p. 608-613. 